\title{
Vitamin D status and its determinants in adolescents from the Northern Ireland Young Hearts 2000 cohort
}

\author{
Tom R. Hill ${ }^{1}$, Alice A. Cotter ${ }^{1}$, Sarah Mitchell ${ }^{1}$, Colin A. Boreham ${ }^{3}$, Werner Dubitzky ${ }^{4}$, \\ Liam Murray $^{6}$, J. J. Strain ${ }^{5}$, Albert Flynn ${ }^{1}$, Paula J. Robson ${ }^{5}$, Julie M. W. Wallace ${ }^{5}$, Mairead Kiely ${ }^{1}$ \\ and Kevin D. Cashman ${ }^{1,2 *}$ \\ ${ }^{1}$ Department of Food and Nutritional Sciences and ${ }^{2}$ Department of Medicine, University College, Cork, Republic of Ireland \\ ${ }^{3}$ UCD Institute for Sport and Health, University College, Dublin, Republic of Ireland \\ ${ }^{4}$ Systems Biology Research Group and ${ }^{5}$ Northern Ireland Centre for Food and Health, University of Ulster, Coleraine, UK \\ ${ }^{6}$ Department of Epidemiology and Public Health, Queens University, Belfast, UK
}

(Received 21 June 2007 - Revised 11 September 2007 - Accepted 13 September 2007 - First published online 15 January 2008)

Despite recent concerns about the high prevalence of sub-clinical vitamin D deficiency in adolescents, relatively few studies have investigated the underlying reasons. The objective of the present study was to investigate the prevalence and predictors of vitamin D inadequacy among a large representative sample of adolescents living in Northern Ireland $\left(54-55^{\circ} \mathrm{N}\right)$. Serum concentrations of 25-hydroxyvitamin D $(25(\mathrm{OH}) \mathrm{D})$ were analysed by enzyme-immunoassay in a subgroup of 1015 of the Northern Ireland Young Hearts 2000 cohort; a cross-sectional study of 12 and 15 yearold boys and girls. Overall mean 25(OH)D concentration throughout the year was $64 \cdot 3$ (range 5-174) nmol/1; 56.7 and 78.1 nmol/1 during winter and summer, respectively. Reported intakes of vitamin D were very low (median $1.7 \mu \mathrm{g} / \mathrm{d}$ ). Of those adolescents studied, $3 \%$ and $36 \%$ were vitamin D deficient and inadequate respectively, as defined by serum $25(\mathrm{OH}) \mathrm{D}$ concentrations $<25$ and $<50 \mathrm{nmol} / \mathrm{l}$. Of the subjects, $46 \%$ and $17 \%$ had vitamin D inadequacy during winter and summer respectively. Gender differences were also evident with $38 \%$ and $55 \%$ of boys and girls respectively classified as vitamin $\mathrm{D}$ inadequate during winter $(P<0.001)$. Predictors of vitamin $\mathrm{D}$ inadequacy during winter were vitamin $\mathrm{D}$ intake and gender. In conclusion, there is a high prevalence of vitamin D inadequacy in white-skinned adolescents in Northern Ireland, particularly during wintertime and most evident in girls. There is a clear need for dietary recommendations for vitamin $\mathrm{D}$ in this age group and for creative strategies to increase overall vitamin D status in the population.

Serum 25-hydroxyvitamin D: Vitamin D insufficiency: Determinants: Season: Gender: Adolescents

It is well established that prolonged and severe clinical vitamin D deficiency (represented as serum 25-hydroxyvitamin $\mathrm{D}(25(\mathrm{OH}) \mathrm{D}))$ concentrations $<10-25 \mathrm{nmol} / \mathrm{l})$ leads to rickets in children and osteomalacia in adults ${ }^{(1)}$. Currently in the UK, a plasma level of $25 \mathrm{nmol} / 125(\mathrm{OH}) \mathrm{D}$ is used as the lower threshold for vitamin D status ${ }^{(1)}$. There is also a growing body of evidence to suggest that less severe degrees of deficiency, or sub-clinical deficiency (serum 25(OH)D concentrations $<50 \mathrm{nmol} / \mathrm{l}$ ), may be associated with increased risk of a wide range of chronic diseases, including tuberculosis, rheumatoid arthritis, multiple sclerosis, inflammatory bowel diseases, CVD, hypertension and certain cancers ${ }^{(2,3)}$. With this in mind, it is of concern that a high prevalence of sub-clinical deficiency has been reported in adults from many countries (see reviews ${ }^{(4-7)}$ ).

Until recently, it had been assumed that children and adolescents were not at risk of low vitamin D status because of their outdoor activities and dietary intake ${ }^{(3)}$. However, a number of recent studies in adolescents have revealed a high prevalence of vitamin D insufficiency in Europe ${ }^{(8-15)}$, the USA ${ }^{(16-19)}$ and elsewhere (the Lebanon ${ }^{(20)}$, New Zealand ${ }^{(21,22)}$, Tasmania ${ }^{(23)}$ ), especially during the winter months. Several of the afore-mentioned studies have also provided evidence of a possible adverse effect of low vitamin D status for adolescent bone growth and strength ${ }^{(8,11,12)}$. Holick in his recent review of childhood vitamin $\mathrm{D}$ deficiency highlights evidence that living at latitudes above $35^{\circ} \mathrm{N}$ for the first 10 years of life increases risk of multiple sclerosis by $100 \%$, as well as increasing risk of several other autoimmune diseases ${ }^{(24)}$. Thus, failure to address low vitamin D status among adolescents could have serious long-term implications for public health.

Despite concerns about the high prevalence of low vitamin D status in adolescents, relatively few studies have investigated the potential determinants of vitamin D status in this life-stage group. A small number of studies of non-nationally representative samples of adolescent girls in Europe and USA have shown that season, sun exposure, ethnicity and race, as well as body weight, are determinants of vitamin D status $^{(11,13,18)}$. Rockell et al. reported that ethnicity, season and, to lesser degrees, obesity and gender were significant 
predictors of year-round vitamin D status in a nationally representative sample of New Zealand children and adolescents ${ }^{(22)}$. Knowledge of such determinants is of importance for the development of public health strategies for prevention of low vitamin D status. Despite our relatively northerly latitude $\left(51-55^{\circ} \mathrm{N}\right)$, there are almost no data on vitamin $\mathrm{D}$ status and its determinants among adolescents in Ireland. Therefore, we examined vitamin $\mathrm{D}$ status and its determinants during winter and summer in a representative sample of adolescents in Northern Ireland, a region with a high prevalence of diseases associated with low vitamin D status, including $\mathrm{CVD}^{(25)}$, multiple sclerosis ${ }^{(26)}$ and colon cancer $^{(27)}$.

\section{Subjects and methods}

\section{Design}

The Young Hearts 2000 (YH2000) survey is the second in a series of cross-sectional studies examining a representative sample of adolescents in Northern Ireland. The primary aim of YH2000 was to identify the prevalence of risk factors for CHD in adolescents aged 12 and 15 years. Details of subject recruitment, inclusion and exclusion criteria, response rate and ethical approval have been described elsewhere ${ }^{(28-30)}$. During the months of January, February, March, April, May, June, September, October, November and December, $11 \%$, $16 \%, 16 \%, 6 \%, 2 \%, 7 \%, 10 \%, 11 \%, 11 \%$ and $11 \%$ of the group were sampled respectively. None of the subjects was sampled during July or August owing to summer vacation. Given that Northern Ireland is at a latitude where UVB intensity is insufficient to promote dermal synthesis of vitamin D between November to March $^{(31)}$, we defined winter as November to March, and summer as April to October. Complete records were available for 1015 adolescents who had provided a blood sample and for whom data on pubertal status, anthropometry, habitual physical activity and food intakes were also available.

\section{Anthropometry, lifestyle and dietary data}

Standing height and body weight were measured as described previously ${ }^{(29)}$. Pubertal status of each subject was assessed by a paediatrician using visual signs such as non-genital secondary hair growth, vocal timbre, body habitus, general muscular development and overall breast development in girls. Lifestyle data and physical activity data were obtained from questionnaires, as described previously ${ }^{(29,32)}$. Dietary data were collected by a nutritionist-administered $7 \mathrm{~d}$ diet history method ${ }^{(33)}$. Energy and nutrient intakes were calculated using a computer program (WISP; Tinuviel Software, Warrington, UK) based on McCance and Widdowson's Composition of Foods ${ }^{(34)}$.

\section{Collection and preparation of samples}

Blood was collected by venipuncture into a vacutainer tube with no additive and processed to serum, which was immediately stored at $-80^{\circ} \mathrm{C}$ until required for analysis.

\section{Experimental techniques}

Serum 25-hydroxyvitamin D. 25(OH)D concentrations were measured in serum samples using ELISA (OCTEIA ${ }^{\circledR} 25$ Hydroxy Vitamin D; Immuno Diagnostic Systems, Ltd., Boldon, UK). The intra- and inter-assay CV for the ELISA method was $5.9 \%$ and $6.6 \%$, respectively. The quality and accuracy of serum $25(\mathrm{OH}) \mathrm{D}$ analysis in our laboratory is assured on an ongoing basis by participation in the Vitamin D External Quality Assessment Scheme (Charing Cross Hospital, London, UK).

\section{Statistical analysis}

Statistical analysis of the data was conducted using $\operatorname{SPSS}^{\circledR}$ for Windows ${ }^{\mathrm{TM}}$ Version 12.0 (SPSS, Inc., Chicago, IL, USA). Serum $25(\mathrm{OH}) \mathrm{D}$ concentrations and dietary vitamin D intakes were not normally distributed and, therefore, values were logarithmically (natural $\log$ ) transformed prior to statistical analysis, to achieve near-normal distributions. Differences in age, height, weight, BMI, physical activity, serum 25(OH)D and dietary vitamin $\mathrm{D}$ and $\mathrm{Ca}$ between the genders and age-groupings were examined using unpaired Student's $t$ tests. Tests for independence were used to compare demographic variables such as age-grouping, gender, season of sampling and pubertal status between those included in current analysis $(n$ 1015) and the complete YH2000 dataset ( $n$ 2017). Differences in proportion of vitamin D deficiency/inadequacy between genders and age-groupings were assessed by $\chi^{2}$ tests. Two-way ANOVA was used to investigate gender-season interactions on serum $25(\mathrm{OH}) \mathrm{D}$ concentrations. Tests for independence were used to compare serum $25(\mathrm{OH}) \mathrm{D}$ concentrations between boys and girls during winter and summer, separately. Multiple logistic regression was used to investigate predictors of risk of vitamin D inadequacy (serum $25(\mathrm{OH}) \mathrm{D}<50 \mathrm{nmol} / \mathrm{l}$ ), whilst adjusting for possible confounding factors. The following categorical variables were included: season (coded as: 0, winter, November-March; 1, summer, April-October); gender (coded as: 0 , female; 1 , male); pubertal status (coded as: 0 , pre-puberty; 1 , post-puberty); vitamin $\mathrm{D}$ intake above or below the median (coded as: 0, greater than median; 1 , less than median); $\mathrm{Ca}$ intake above or below the median (coded as: 0, greater than median; 1, less than median); physical activity level above or below the median (coded as: 0, greater than median; 1, less than median). The continuous numerical variable BMI $\left(\mathrm{kg} / \mathrm{m}^{2}\right)$ was also included. Multiple linear regression analysis was performed to identify independent predictors of serum $25(\mathrm{OH}) \mathrm{D}$. The following categorical variables were included: season (coded as: 0, winter, November-March; 1, summer, April-October); gender (coded as: 0, female; 1, male); age-grouping (coded as: 0, aged 12 years; 1 , aged 15 years); pubertal status (coded as 0, pre-puberty; 1 , post-puberty). The continuous numerical variables, BMI $\left(\mathrm{kg} / \mathrm{m}^{2}\right)$, vitamin D intake $(\mu \mathrm{g} / \mathrm{d})$, Ca intake $(\mathrm{mg} / \mathrm{d})$ and physical activity score were also included. $P$ values $<0.05$ were considered statistically significant.

\section{Results}

\section{Baseline characteristics of adolescents}

Characteristics of the adolescents included in the current analysis ( $n$ 1015) were compared with those of all participants in 
the YH2000 study ( $n$ 2017), which was a representative sample of adolescents in Northern Ireland (Table 1). No significant differences were evident between these two groups (Table 1).

\section{Vitamin D status and vitamin D intakes}

The mean, standard deviation and distribution of serum $25(\mathrm{OH}) \mathrm{D}$ concentrations throughout the year in the sample of 1015 adolescents, and in each age and gender group, separately, are shown in Table 2 . While all girls had a slightly lower mean year-round serum $25(\mathrm{OH}) \mathrm{D}$ concentration compared with boys $(P=0 \cdot 054)$, a difference between the genders was significant in 15 year-olds $(P=0.018)$ but not in 12 yearolds $(P=0.81)$. Two-way ANOVA showed that serum $25(\mathrm{OH}) \mathrm{D}$ concentration in the entire group was significantly affected by season (mean 56.7 (SD 24.3) $\mathrm{nmol} / \mathrm{l}$ and 78.1 (SD 27.1) nmol/l, for winter ( $n$ 657) and summer ( $n$ 358), respectively; $P<0.0001)$ but not gender $(P>0.05$; data in Table 2); there was, however, a significant interaction between these two factors $(P<0.001)$. While all girls $(n 326)$ had a significantly lower mean wintertime serum $25(\mathrm{OH}) \mathrm{D}$ concentration compared with all boys ( $n$ 331) (mean $52 \cdot 3$ (SD 22.6) $\mathrm{nmol} / 1$ and 61.1 (SD 25.1) nmol/1, respectively; $P<0.001$ ), all girls ( $n$ 184) had significantly higher mean summertime serum 25(OH)D concentrations compared with all boys (n 174) (mean 81.5 (SD 23.9) $\mathrm{nmol} / \mathrm{l}$ and 74.7 (SD 29.7) nmol/l, respectively; $P=0.002)$.

Table 1. Characteristics of Northern Ireland Young Hearts 2000 Project participants entire cohort and those in the current analysis of vitamin D status§

\begin{tabular}{|c|c|c|c|c|}
\hline \multirow[b]{2}{*}{ Characteristic } & \multicolumn{2}{|c|}{$\begin{array}{c}\text { All survey } \\
\text { participants* }\end{array}$} & \multicolumn{2}{|c|}{$\begin{array}{c}\text { Participants with a } \\
\text { serum } 25(\mathrm{OH}) \mathrm{D} \\
\text { measurement } \dagger\end{array}$} \\
\hline & \multicolumn{2}{|c|}{$\%$} & \multicolumn{2}{|c|}{$\%$} \\
\hline \multicolumn{5}{|l|}{ Gender } \\
\hline Boys & \multicolumn{2}{|c|}{51} & \multicolumn{2}{|c|}{50} \\
\hline Girls & \multicolumn{2}{|c|}{49} & \multicolumn{2}{|c|}{50} \\
\hline \multicolumn{5}{|l|}{ Age (years) } \\
\hline 12 & \multicolumn{2}{|c|}{52} & \multicolumn{2}{|c|}{52} \\
\hline 15 & \multicolumn{2}{|c|}{48} & \multicolumn{2}{|c|}{48} \\
\hline \multicolumn{5}{|l|}{ Season of sampling $\ddagger$} \\
\hline Winter & \multicolumn{2}{|c|}{67} & \multicolumn{2}{|c|}{65} \\
\hline Summer & \multicolumn{2}{|c|}{33} & \multicolumn{2}{|c|}{35} \\
\hline \multicolumn{5}{|l|}{ Tanner score } \\
\hline 1 & \multicolumn{2}{|c|}{3} & \multicolumn{2}{|c|}{2} \\
\hline 2 & \multicolumn{2}{|c|}{33} & \multicolumn{2}{|c|}{33} \\
\hline 3 & \multicolumn{2}{|c|}{19} & \multicolumn{2}{|c|}{20} \\
\hline 4 & \multicolumn{2}{|c|}{35} & \multicolumn{2}{|c|}{39} \\
\hline \multirow[t]{2}{*}{5} & \multicolumn{2}{|c|}{10} & \multicolumn{2}{|c|}{6} \\
\hline & Mean & SD & Mean & SD \\
\hline Height (m) & 1.60 & 0.002 & 1.60 & 0.003 \\
\hline Weight (kg) & 52.9 & 0.3 & 53.0 & 0.4 \\
\hline $\operatorname{BMI}\left(\mathrm{kg} / \mathrm{m}^{2}\right)$ & $20 \cdot 5$ & 0.1 & 20.5 & 0.1 \\
\hline Vitamin D intake $(\mu \mathrm{g} / \mathrm{d})$ & $2 \cdot 7$ & 3.4 & $2 \cdot 6$ & $3 \cdot 2$ \\
\hline $\mathrm{Ca}$ intake $(\mathrm{mg} / \mathrm{d})$ & 968 & 381 & 973 & 390 \\
\hline
\end{tabular}

25(OH)D, 25-hydroxyvitamin D.

* In the Young Hearts Project, a participant was defined as an adolescent who completed a diet history $(n$ 2017)

$\dagger(n$ 1015).

$\ddagger$ Winter was defined as months November to March and summer was defined as months April to October.

$\S$ For details of subjects and procedures, see Subjects and methods.
The mean, standard deviation, median and 5th and 95th percentiles of vitamin $\mathrm{D}$ and $\mathrm{Ca}$ intakes (from food and supplements) were $2.6,3 \cdot 2,1.7,0.6$ and $10.5 \mu \mathrm{g}$ and 973,390 , 907, 467 and $1676 \mathrm{mg} / \mathrm{d}$, respectively. Vitamin D and Ca intakes were significantly higher $(P<0.0001)$ in boys than girls $(3.0$ v. $2.2 \mu \mathrm{g} / \mathrm{d}$ (vitamin D); 1089 v. $858 \mathrm{mg} / \mathrm{d}(\mathrm{Ca})$ ). There were no significant differences in vitamin $\mathrm{D}$ or $\mathrm{Ca}$ intakes between 12 and 15 year-olds (data not shown). Mean physical activity score was significantly higher $(P<0.05)$ in boys than girls (30 v. 18, respectively). In addition, mean physical activity score was significantly higher $(P<0.001)$ in boys than girls during summertime (data not shown).

\section{Prevalence of vitamin $D$ deficiency and inadequacy}

Cumulative percentages of adolescents with serum 25(OH)D concentrations ranging from $<10 \mathrm{nmol} / 1$ to $<120 \mathrm{nmol} / \mathrm{l}$, which have been variably suggested as cut-off values for defining vitamin D deficiency to insufficiency ${ }^{(1,2,3)}$, are shown in Fig. 1. Stratification of the adolescents by sampling period showed that the proportion of subjects with serum $25(\mathrm{OH}) \mathrm{D}$ concentrations $<50 \mathrm{nmol} / \mathrm{l}$ (the cut-off value that defines sub-clinical deficiency) was $46 \%$ during winter and $17 \%$ during summer. During winter, $38 \%$ of boys and $55 \%$ of girls had serum $25(\mathrm{OH}) \mathrm{D}<50 \mathrm{nmol} / 1(P<0.001)$.

Mean daily vitamin $D$ intakes in subjects with serum $25(\mathrm{OH}) \mathrm{D}$ concentrations $<25$ and $\geq 25 \mathrm{nmol} / 1$ were 1.5 and $2.6 \mu \mathrm{g} / \mathrm{d}$, respectively $(P=0.003)$. Mean daily vitamin $\mathrm{D}$ intakes in subjects with serum $25(\mathrm{OH}) \mathrm{D}$ concentrations $<50$ and $\geq 50 \mathrm{nmol} / \mathrm{l}$ were 2.1 and $2.9 \mu \mathrm{g} / \mathrm{d}$, respectively $(P<0.001)$.

\section{Determinants of serum 25-hydroxyvitamin D levels}

Potential determinants of serum 25(OH)D levels throughout the year were assessed using multiple linear regression analysis. $\mathrm{Ca}$ intake, gender and physical activity score were nonsignificant $(P>0.05)$ determinants of serum 25(OH)D levels. Being sampled during the sunnier half of the year (i.e. summer to autumn) ( $\beta 0.370$; CI $0.318,0.423 ; P<0.0001)$, vitamin D intake $(\beta 0.083$; CI $0.050,0.115 ; P<0.0001)$ and increasing BMI $(\beta 0.008$; CI $0.001,0.015 ; P=0.035)$ were positively associated with serum $25(\mathrm{OH}) \mathrm{D}$ levels. Limiting the analysis to only those subjects sampled during winter showed that vitamin D intake ( $\beta$ 0.998; CI 0.478, $1.518 ; P<0.0001)$ and gender $(\beta$ 6.041; CI 2.162, 9.919; $P=0.002)$ were the only two significant determinants of serum $25(\mathrm{OH}) \mathrm{D}$ levels.

\section{Predictors of low vitamin D status}

Multiple logistic regression analysis was used to identify the factors contributing to serum $25(\mathrm{OH}) \mathrm{D}$ concentrations $<50 \mathrm{nmol} / \mathrm{l}$ (Table 3). Winter sampling time and low vitamin D intake were significant predictors of low vitamin D status (Table 3). Ca intake, gender, age, BMI, pubertal status and physical activity were not significant predictors of low vitamin D status (data not shown). For those subjects sampled during winter, a vitamin $D$ intake below the median of $1.7 \mu \mathrm{g} / \mathrm{d}$ (OR 1.589 (95\% CI 1.131, 2.232); $P=0.008$ ) and being female (OR 1.460 (95\% CI 1.017, 2.097); $P=0.04)$ were 
Table 2. Serum 25-hydroxyvitamin D (S-25(OH)D) concentrations throughout the year in healthy adolescents in Northern Ireland $\dagger$

\begin{tabular}{|c|c|c|c|c|c|c|c|}
\hline & \multirow[b]{2}{*}{ All subjects } & \multicolumn{3}{|c|}{ Boys } & \multicolumn{3}{|c|}{ Girls } \\
\hline & & All & 12 year-old & 15 year-old & All & 12 year-old & 15 year-old \\
\hline \multicolumn{8}{|l|}{$\mathrm{S}-25(\mathrm{OH}) \mathrm{D}(\mathrm{nmol} / \mathrm{l})$} \\
\hline$n$ & 1015 & 505 & 266 & 239 & 510 & 260 & 250 \\
\hline Mean & $64 \cdot 3$ & $65 \cdot 8$ & $65 \cdot 2$ & 66.5 & $62 \cdot 8$ & $64 \cdot 3$ & $61 \cdot 2$ \\
\hline SD & $27 \cdot 3$ & $27 \cdot 5$ & $27 \cdot 3$ & $27 \cdot 8$ & 27 & $25 \cdot 8$ & $28 \cdot 1$ \\
\hline Median & $60 \cdot 1$ & $62 \cdot 5$ & $61 \cdot 1$ & $63 \cdot 6$ & $58 \cdot 2$ & 59 & $57 \cdot 6$ \\
\hline 5th Percentile & $27 \cdot 8$ & 29.5 & $30 \cdot 4$ & $27 \cdot 3$ & 27.5 & $29 \cdot 7$ & 23.9 \\
\hline 95th Percentile & $116 \cdot 4$ & $117 \cdot 8$ & 120 & $117 \cdot 4$ & $110 \cdot 9$ & $110 \cdot 5$ & $113 \cdot 3$ \\
\hline Geometric mean & 58.6 & $60 \cdot 2$ & 59.9 & 60.5 & $57 \cdot 1^{*}$ & $59 \cdot 2$ & $54 \cdot 9^{\star \star}$ \\
\hline
\end{tabular}

significant predictors of low vitamin D status, after adjusting for possible confounders. On the other hand, limiting the analysis to only those subjects sampled during summer did not reveal any significant predictors of low vitamin D status among those tested.

\section{Discussion}

It is clearly recognised that serum/plasma $25(\mathrm{OH}) \mathrm{D}$ levels below $12.5 \mathrm{nmol} / \mathrm{l}$ can result in bone diseases, such as rickets in children and osteomalacia in adults ${ }^{(35)}$. There is also evidence that circulating $25(\mathrm{OH}) \mathrm{D}$ levels below $20-25 \mathrm{nmol} / \mathrm{l}$ may result in rickets and osteomalacia in the longer term $^{(1,36)}$. In the present study, $2.9 \%$ of a representative sample of 12 and 15 year-old adolescents from Northern Ireland had serum $25(\mathrm{OH}) \mathrm{D}$ concentrations $<25 \mathrm{nmol} / \mathrm{l}$ throughout the year. Only three other studies to date have used a nationally representative sample. Data from the UK NDNS ${ }^{9}$ showed that $11-16 \%$ of 11-18 year-old adolescents in England, Wales and Scotland had serum 25(OH)D $<25 \mathrm{nmol} / \mathrm{l}$ throughout the year. One fundamental difference between the NDNS sample and the current cohort is the homogeneity of the YH2000 sample in terms of race; the overwhelming majority of the adolescents in the current sample were white as at the time of sampling, ethnic diversity within the population of Northern Ireland was almost non-existent. In contrast, the NDNS included a representative sample from across Great Britain, which has a more ethnically diverse population profile. Skin colour is an important predictor of vitamin D status. The efficiency of synthesis of cholecalciferol is negatively related to the extent of skin pigmentation; thus, the lower prevalence of vitamin D deficiency observed in the YH2000 cohort than in the NDNS is most likely related to differences in the capacity for vitamin D synthesis. In the

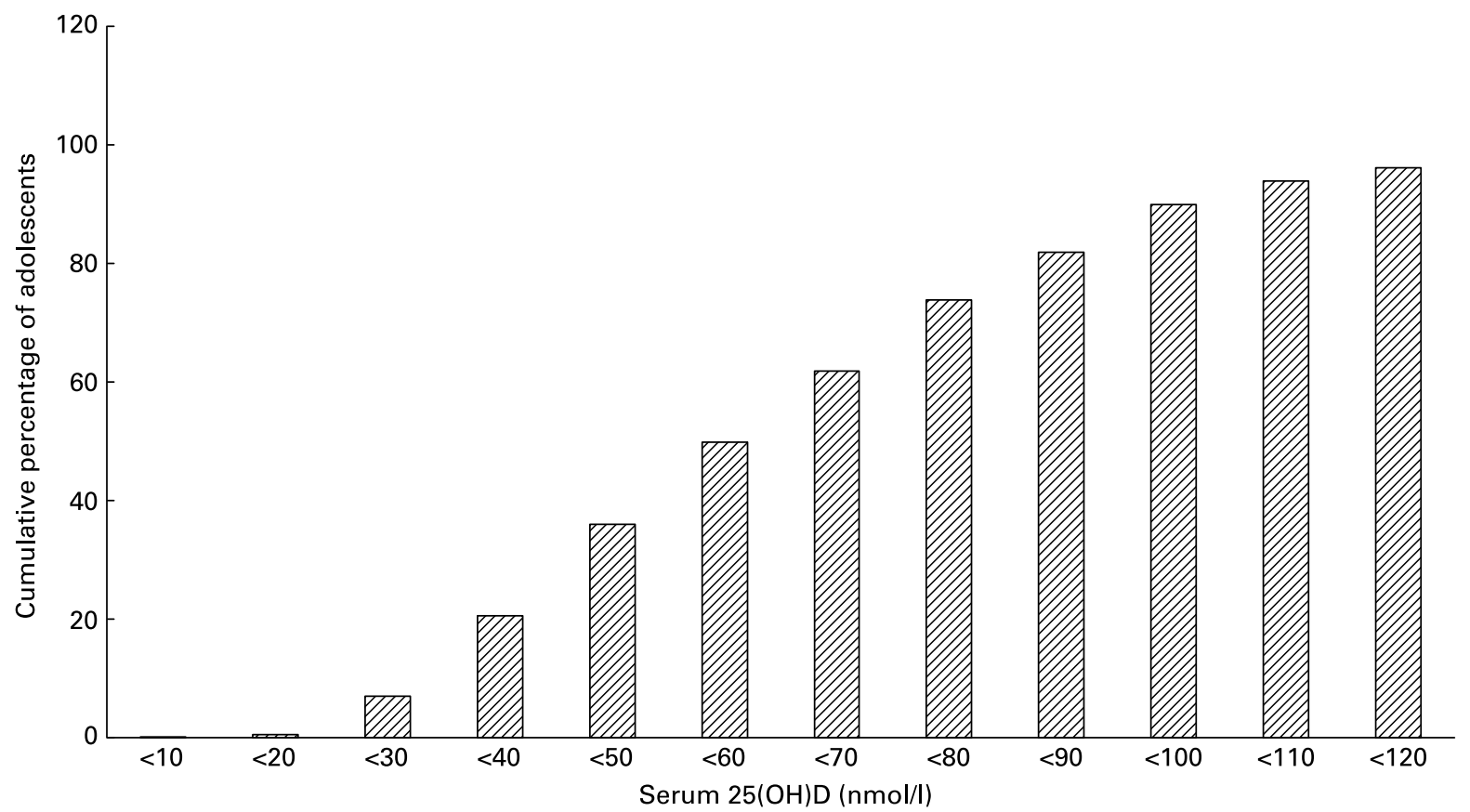

Fig. 1. Cumulative percentage of Northern Ireland adolescents ( $n$ 1015) with serum 25 -hydroxyvitamin $\mathrm{D}(25(\mathrm{OH}) \mathrm{D})$ between 10 and $120 \mathrm{nmol} / \mathrm{l}$. For details of subjects and procedures, see Subjects and methods. 
Table 3. Multiple logistic regression analysis of predictors of serum $25(\mathrm{OH}) \mathrm{D}$ values $<50 \mathrm{nmol} / \mathrm{l}$ in 1015 Northern Ireland adolescents

\begin{tabular}{lccc}
\hline & OR & $95 \% \mathrm{Cl}$ & $P$ value \\
\hline Time of year & & & \\
$\quad$ April-October (summer) & 1.00 & - & - \\
$\quad$ November-March (winter) & 4.44 & $3.23,6.11$ & $<0.0001$ \\
Vitamin D intake & & & - \\
$\quad$ Greater than median $(>1.7 \mu \mathrm{g} / \mathrm{d})$ & 1.00 & - & - \\
$\quad$ Less than median $(<1.7 \mu \mathrm{g} / \mathrm{d})$ & 1.58 & $1.20,2.07$ & $<0.001$ \\
\hline
\end{tabular}

*For details of subjects and procedures, see Subjects and methods.

US-based National Health and Nutrition Examination Survey study, $\leq 1 \%$ of $12-19$ year-olds had serum $25(\mathrm{OH}) \mathrm{D}$ $<25 \mathrm{nmol} / \mathrm{l}^{(16)}$, although this is likely to be an underestimate because vitamin D status was measured in northern United States during summer and in southern United States during winter. A study in New Zealand found that $4 \%$ of adolescents aged $11-14$ years had serum $25(\mathrm{OH}) \mathrm{D}<17.5 \mathrm{nmol} / \mathrm{l}^{(22)}$.

Circulating 25(OH)D concentrations greater than $25 \mathrm{nmol} / \mathrm{l}$ but less then $50 \mathrm{nmol} / 1$ reflect sub-clinical vitamin D deficiency, which is associated with elevated parathyroid hormone with consequences for bone turnover rates, at least in adults ${ }^{(37)}$. Furthermore, serum $25(\mathrm{OH}) \mathrm{D}$ concentration $<50 \mathrm{nmol} / \mathrm{l}$ has also been linked to the development of various chronic diseases (e.g. hypertension, CVD, diabetes mellitus, as well as some inflammatory and autoimmune diseases and some forms of cancer). ${ }^{(2,3)}$ Over one-third (36\%) of adolescents in the present study had $25(\mathrm{OH}) \mathrm{D}$ concentrations $<50 \mathrm{nmol} / \mathrm{l}$ across the year and the prevalence of vitamin D inadequacy, or low vitamin D status, was much higher $(48-52 \%)$ in subjects sampled during winter (November-March). These findings are broadly in line with those of the three previously mentioned studies of nationally representative samples of adolescents ${ }^{(9,16,22)}$ and in keeping with several studies that investigated the prevalence of vitamin D inadequacy in adolescents in Europe ${ }^{(8,10-14)}$, the $\mathrm{USA}^{(16-19)}$ and elsewhere ${ }^{(20,21,23)}$.

In the current study, girls had lower wintertime mean serum $25(\mathrm{OH}) \mathrm{D}$ levels than boys, although girls had higher levels during summertime. The gender difference during summertime might relate to a higher proportion of girls (72\%) being sampled in late summer (September/October; when vitamin D status would be at its peak) compared with only $43 \%$ of boys being sampled during that time. Those sampled in earlier summer (April-June) would be expected to have lower vitamin D status. There was an increased proportion of girls with low $(<50 \mathrm{nmol} / \mathrm{l}) 25(\mathrm{OH}) \mathrm{D}$ levels throughout the year (39\% v. $32 \%$, for girls and boys, respectively) as well as in winter only ( $55 \%$ v. $38 \%$, for girls and boys, respectively). While not evident in the UK-based NDNS study of adolescents $^{(9)}$, this lower vitamin D status among girls has also been reported in the national studies of children and adolescents in the $\mathrm{USA}^{(16)}$ and New Zealand ${ }^{(22)}$. The reason for this apparent gender difference is unclear. However, in the current study, girls had lower vitamin D intakes than boys. It is also interesting to note that subjects with vitamin D deficiency and insufficiency had significantly lower vitamin D intakes compared with those in vitamin D-replete subjects. Multiple linear regression analysis of subjects sampled in winter showed that being female and low vitamin D intake were the only two significant determinants of serum
25(OH)D levels. Rockell et al. suggested that the difference in vitamin $\mathrm{D}$ status between the genders was acting as a surrogate marker for sunlight exposure through an association with physical activity ${ }^{(2)}$. In the present study, physical activity was significantly higher in boys than girls, even during summertime. Physical activity was not a determinant of serum $25(\mathrm{OH}) \mathrm{D}$ levels in these adolescents. The physical activity score, however, included activity that is both indoorand outdoor-based.

To explore the reasons for the high prevalence of low vitamin D status in the adolescents in Northern Ireland, we investigated the potential predictors of vitamin $\mathrm{D}$ inadequacy (serum $25(\mathrm{OH}) \mathrm{D}<50 \mathrm{nmol} / \mathrm{l})$. Not surprisingly, season was the major determinant of vitamin D status, a finding shown in many studies of adults ${ }^{(38,39)}$, and in the New Zealand study of determinants of low vitamin D status in children and adolescents ${ }^{(22)}$. Potentially of concern was our observation that $13 \%$ of adolescents living in Northern Ireland had low vitamin D status during summertime, at a time when vitamin D synthesis and status would be expected to be optimum ${ }^{(4)}$. As season was such a major predictor, we repeated the analysis in the subgroups sampled during winter- and summertime separately. During winter, low vitamin D intake (less than $1.7 \mu \mathrm{g} / \mathrm{d}$ ) and being female were significant predictors of having a serum $25(\mathrm{OH}) \mathrm{D}$ value of $<50 \mathrm{nmol} / \mathrm{l}$.

There is no dietary recommendation for vitamin D for adolescents in the UK, as there is an assumption that sun exposure will provide for adequate status during summer and allow for stores to be laid down to support vitamin D status in winter ${ }^{1}$. This lack of a dietary recommendation appears unwise when $12 \%$ and $47 \%$ of UK adolescents (aged 11-18 years) have plasma $25(\mathrm{OH}) \mathrm{D}$ concentrations that are reflective of serious and mild deficiency, respectively ${ }^{(9)}$. In contrast, the US Institute of Medicine recommends $5 \mu \mathrm{g} / \mathrm{d}$ for adolescents ${ }^{(40)}$, an intake level that only $10 \%$ of the current sample managed to achieve. These low intakes are in line with similar reports from several countries ${ }^{(8,9,13,15,41,42)}$. For example, data from the NDNS show that the mean daily intake of vitamin D for adolescents (aged 11-18 years) in the UK is $2.6 \mu \mathrm{g}^{(9)}$. For individuals living in Ireland, the UK and elsewhere in Europe and North America at latitudes above $37^{\circ} \mathrm{N}$, low intakes of vitamin D may take on increased importance during wintertime when sunlight is of insufficient intensity to stimulate dermal vitamin D synthesis.

We did not identify any significant physiological or lifestyle predictors of low vitamin D status during summer, indicating that UVB exposure, which was not directly assessed in the current study, was the overriding determinant of vitamin D status at this time. Despite being by far the most efficacious method of improving vitamin D status ${ }^{(3)}$, recommendations for increased UVB exposure are fraught with public health difficulties in relation to evidence for increased risk of skin cancer. Thus, a dietary strategy (including supplemental and/ or fortification sources of vitamin D) appears a more acceptable mode of improving vitamin D status of the population, including adolescents. More research is needed to define the levels of intakes required and the best strategies to achieve these intakes on a population basis. The lack of an international consensus on cut-off levels for vitamin D deficiency/insufficiency is certainly a limitation in terms of better defining dietary requirements. While there are several 
reasons for this uncertainty ${ }^{(43)}$, it is further complicated by methodological issues surrounding analysis of serum $25(\mathrm{OH}) \mathrm{D}$ levels. Different methods of analysis can produce different serum $25(\mathrm{OH}) \mathrm{D}$ levels, as illustrated recently in round robin analyses of the Vitamin D External Quality Assessment Scheme samples ${ }^{(44-46)}$. In addition, significant variation between laboratories using the same analytical technique can exist due to operator bias. For these reasons, participation of laboratories in the Vitamin D External Quality Assessment Scheme is highly recommended, as well as the future inclusion of standard reference materials for serum $25(\mathrm{OH}) \mathrm{D}$, which are currently being developed in the USA.

In conclusion, there was a high prevalence of low vitamin D status among adolescents living in Northern Ireland at latitudes of $54-55^{\circ} \mathrm{N}$, most marked during the winter months. This seems to be a consequence of the failure of a low dietary intake of vitamin $\mathrm{D}$ to compensate for the lack of dermal synthesis during this period. Increased emphasis needs to be given to exploring strategies for improving vitamin D status in adolescents.

\section{Acknowledgements}

This project was financially supported by the Higher Education Authority under their Strand 1: North/South Programme for Collaborative Research and the Northern Ireland Department of Health, Social Services and Public Safety. None of the authors has a conflict of interest.

\section{References}

1. Department of Health (1998) Nutrition and Bone Health: With Particular Reference to Calcium and Vitamin D. Report on Health and Social Subjects (49). London: The Stationery Office.

2. Zittermann A (2003) Vitamin D in preventive medicine: are we ignoring the evidence? Br J Nutr 89, 552-572.

3. Holick MF (2004) Sunlight and vitamin D for bone health and prevention of autoimmune diseases, cancers and cardiovascular disease. Am J Clin Nutr 80, 1678S-1688S.

4. McKenna MJ (1992) Differences in vitamin D status between countries in young adults and the elderly. Am J Med 93, 69-77.

5. van der Wielen RP, Lowik MR, van den Berg H, de Groot LC, Haller J, Moreiras O \& van Staveren WA (1995) Serum vitamin D concentrations among elderly people in Europe. Lancet 346, 8969, 207-210.

6. Lips P, Duong T, Oleksik A, Black D, Cummings S, Cox D \& Nickelsen T (2001) A global study of vitamin D status and parathyroid function in postmenopausal women with osteoporosis: baseline data from the multiple outcomes of raloxifene evaluation clinical trial. J Clin Endocrinol Metab 86, 1212-1221.

7. Lips P, Hosking D, Lippuner K, Norquist JM, Wehren L, Maalouf G, Ragi-Eis S \& Chandler J (2006) The prevalence of vitamin D inadequacy amongst women with osteoporosis: an international epidemiological investigation. J Intern Med 260, $245-254$.

8. Lehtonen-Veromaa M, Mottonen T, Nuotio I, Irjala K, Leino A \& Viikari J (2002) Vitamin D and attainment of peak bone mass among peripubertal Finnish girls: a 3-y prospective study. Am J Clin Nutr 76, 1446-1453.

9. Gregory J, Lowe S, Bates CJ, Prentice A, Jackson LV, Smithers G, Wenlock R \& Farron M (2000) National Diet and Nutrition Survey: Young People Aged 4 to 18 Years. London: The Stationery Office.
10. Guillemant J, Le HT, Maria A, Allemandou A, Peres G \& Guillemant S (2001) Wintertime vitamin D deficiency in male adolescents: effect on parathyroid function and response to vitamin D3 supplements. Osteoporos Int 12, 875-879.

11. Outila TA, Karkkainen MUM \& Lamberg-Allardt CJE (2001) Vitamin D status affects serum parathyroid hormone concentrations during winter in female adolescents: associations with forearm bone mineral density. Am J Clin Nutr 74, 206-210.

12. Cheng S, Tylavsky F, Kroger H, et al. (2003) Association of low 25-hydroxyvitamin D concentrations with elevated parathyroid hormone concentrations and low cortical bone density in early pubertal and prepubertal Finnish girls. Am J Clin Nutr 78, 485-492.

13. Andersen R, Molgaard C, Skovgaard LT, et al. (2005) Teenage girls and elderly women living in northern Europe have low winter vitamin D status. Eur J Clin Nutr 59, 533-541.

14. Das G, Crocombe S, McGrath M, Berry J \& Mughal Z (2006) Hypovitaminosis D among healthy adolescent girls attending an inner city school. Arch Dis Child 91, 569-572.

15. Ginty F, Cavadini C, Michaud P-A, et al. (2004) Effects of usual nutrient intake and vitamin D status on markers of bone turnover in Swiss adolescents. Eur J Clin Nutr 58, 1257-1265.

16. Looker A, Dawson-Hughes B, Calvo M, Gunter E \& Sahyoun N (2000) Serum 25-Hydroxyvitamin D status of adolescents and adults in two seasonal subpopulations from NHANES III. Bone 30, 771-777.

17. Gordon C, DePeter K, Feldman H, Grace E \& Emans S (2004) Prevalence of vitamin D deficiency among healthy adolescents. Arch Pediatr Adolesc Med 158, 531-537.

18. Harkness L \& Cromer B (2005) Low levels of 25-hydroxy vitamin D are associated with elevated parathyroid hormone in healthy adolescent females. Osteoporos Int 16, 109-113.

19. Sullivan S, Rosen C, Halteman W, Chen T \& Holick M (2005) Adolescent girls in Maine are at risk for vitamin D insufficiency. J Am Diet Assoc 105, 971-974.

20. El-Hajj Fuleihan G, Nabulsi M, Choucair M, et al. (2001) Hypovitaminosis D in healthy schoolchildren. Pediatrics 107, E53.

21. Skeaff CM \& Green TJ (2004) Serum 25-hydroxyvitamin D status of New Zealand adolescents and adults. Asia Pac J Clin Nutr 13, S47.

22. Rockell JE, Green TJ, Skeaff CM, et al. (2005) Season and ethnicity are determinants of serum 25-hydroxyvitamin D concentrations in New Zealand children aged 5-14y. J Nutr 135, $2602-2608$.

23. Jones G, Blizzard C, Riley MD, Parameswaran V, Greenaway TM \& Dwyer T (1999) Vitamin D levels in prepubertal children in Southern Tasmania: prevalence and determinants. Eur J Clin Nutr 53, 824-829.

24. Holick MF (2006) Resurrection of vitamin D deficiency and rickets. J Clin Invest 116, 2062-2072.

25. Yarnell JW (1998) The PRIME study: classical risk factors do not explain the several fold differences in risk of coronary heart disease between France and Northern Ireland. Prospective Epidemiological Study of Myocardial Infarction. QJM 91, 667-676.

26. McDonnell GV \& Hawkins SA (1998) An epidemiologic study of multiple sclerosis in Northern Ireland. Neurology 50, $423-428$.

27. Kee F, Collins BJ \& Patterson CC (1990) Incidence and site distribution of colorectal cancer in Northern Ireland. Ulster Med $J$ 59, $155-160$.

28. McGartland C, Robson PJ, Murray L, Cran G, Savage MJ, Watkins D, Rooney M \& Boreham C (2003) Carbonated soft drink consumption and bone mineral density in adolescence: the Northern Ireland Young Hearts project. J Bone Miner Res 18, $1563-1569$. 
29. McGartland CP, Robson PJ, Murray LJ, Cran GW, Savage MJ, Watkins DC, Rooney MM \& Boreham CA (2004) Fruit and vegetable consumption and bone mineral density: the Northern Ireland Young Hearts Project. Am J Clin Nutr 80, 1019-1023.

30. Watkins DC, Murray LJ, McCarron P, Boreham CA, Cran GW, Young IS, McGartland C, Robson PJ \& Savage JM (2005) Tenyear trends for fatness in Northern Irish adolescents: the Young Hearts Projects - repeat cross-sectional study. Int J Obes 29, 579-585.

31. Webb AR, Kline L \& Holick MF (1988) Influence of season and latitude on the cutaneous synthesis of vitamin D3: exposure to winter sunlight in Boston and Edmonton will not promote vitamin D3 synthesis in human skin. J Clin Endocrinol Metab 67, 373-378.

32. Pereira MA, FitzGerald SJ, Gregg EW, Joswiak ML, Ryan WJ, Suminski RR, Utter AC \& Zmuda JM (1997) A collection of Physical Activity Questionnaires for health-related research. Med Sci Sports Exerc 29, S1-S205.

33. van Staveren WA, de Boer JO \& Burema J (1985) Validity and reproducibility of a dietary history method estimating the usual food intake during one month. Am J Clin Nutr 42, 554-559.

34. Holland B, Welch AA, Unwin ID, Buss DH, Paul AA \& Southgate DAT (1995) McCance \& Widdowson's The Composition of Foods, 5th ed. Royal Society of Chemistry and Ministry of Agriculture, Fisheries and Food, London: HMSO.

35. Scharla SH (1998) Prevalence of subclinical vitamin D deficiency in different European countries. Osteoporosis Int 8, S7-S12.

36. Basha B, Rao DS, Han ZH \& Parfitt AM (2000) Osteomalacia due to vitamin D depletion: a neglected consequence of intestinal malabsorption. Am J Med 108, 296-300.

37. Lips $\mathrm{P}$ (2004) Which circulating level of 25-hydroxyvitamin D is appropriate? J Steroid Biochem Mol Biol 89-90, 611-614.
38. Hill TR, O'Brien MM, Lamberg-Allardt C, Jakobsen J, Kiely M, Flynn A \& Cashman KD (2006) Vitamin D status of 51-75-year-old Irish women: its determinants and impact on biochemical indices of bone turnover. Public Health Nutr 9, 225-233.

39. Jacques PF, Felson DT, Tucker KL, Mahnken B, Wilson PW, Rosenberg IH \& Rush D (1997) Plasma 25-hydroxyvitamin D and its determinants in an elderly population sample. Am $J$ Clin Nutr 66, 929-936.

40. Institute of Medicine (1997) Food and Nutrition Board. Dietary Reference Intakes: Calcium, Magnesium, Phosphorus, Vitamin $D$, and Fluoride. Washington, DC: National Academy Press.

41. Samuelson G, Bratteby LE, Enghardt H \& Hedgren M (1996) Food habits and energy and nutrient intake in Swedish adolescents approaching the year 2000. Acta Paediatr 415, Suppl., $1-19$.

42. Salamoun MM, Kizirian AS, Tannous RI, et al. (2005) Low calcium and vitamin D intake in healthy children and adolescents and their correlates. Eur J Clin Nutr 59, 177-184.

43. Dawson-Hughes B, Heaney RP, Holick MF, Lips P, Meunier PJ \& Vieth R (2005) Estimates of optimal vitamin D status. Osteopor Int 16, 713-716.

44. Carter GD, Carter R, Jones J \& Berry J (2004) How accurate are assays for 25-hydroxyvitamin D? Data from the international vitamin D external quality assessment scheme. Clin Chem 50, 2195-2197.

45. Carter GD, Carter CR, Gunter E, Jones J, Jones G, Makin HL \& Sufi S (2004) Measurement of vitamin D metabolites: an international perspective on methodology and clinical interpretation. J Steroid Biochem Mol Biol 89-90, 467-471.

46. Carter GD, Jones JC \& Berry JL (2007) The anomalous behaviour of exogenous 25-hydroxyvitamin D in competitive binding assays. J Steroid Biochem Mol Biol 103, 480-482. 